Fixed Point Theory, 21(2020), No. 1, 3-18

DOI: $10.24193 /$ fpt-ro.2020.1.01

http://www.math.ubbcluj.ro/ nodeacj/sfptcj.html

\title{
BEST PROXIMITY POINT OF ZAMFIRESCU CONTRACTIONS OF PEROV TYPE ON REGULAR CONE METRIC SPACES
}

\author{
MUJAHID ABBAS ${ }^{* * *}$, VLADIMIR RAKOČEVIĆ*** AND AZHAR HUSSAIN**** \\ *Government College University Katchery Road, Lahore 54000, Pakistan \\ ** Department of Mathematics and Applied Mathematics, University of Pretoria Hatfield 002, \\ Pretoria, South Africa \\ E-mail: abbas.mujahid@gmail.com \\ *** University of Niš, Faculty of Sciences and Mathematics, Department of Mathematics, \\ 18000 Niš, Serbia \\ E-mail: vrakoc@sbb.rs \\ **** Department of Mathematics, University of Sargodha, Sarogodha-40100, Pakistan \\ Email: hafiziqbal30@yahoo.com
}

\begin{abstract}
T. Zamfirescu, [Fixed point theorems in metric spaces, Arch. Math. (Basel), 23 (1972), 292-298] obtained a very interesting fixed point theorem on complete metric spaces, by combining results of Banach, Kannan and Chatterjea. In this paper, we introduce the concept of ZamfirescuPerov type cyclic contraction and obtain best proximity point theorems for such mapping in the frame work of regular cone metric spaces. Examples are given to support our results. Our results extend and generalize several comparable existing results in literature.
\end{abstract}

Key Words and Phrases: Cone metric spaces, regular cones, best proximity point, Perov contraction, spectral radius.

2010 Mathematics Subject Classification: 47H10, 54H25, 47H09.

Acknowledgments. The authors thankful to the anonymous referees for the useful suggestions and remarks that contributed to the improvement of the manuscript. The second author is supported By Grant No. 174025 of the Ministry of Science, Technology and Development, Republic of Serbia, while the third author is supported by University of Sargodha funded research project No. UOS/ORIC/2016/54.

\section{REFERENCES}

[1] M. Abbas, V. Rakočević, A. Hussain, Proximal cyclic contraction of Perov type on regular cone metric space, J. Adv. Math. Stud., 9(2016), no. 1, 65-71.

[2] M.A. Al-Thagafi, N. Shahzad, Convergence and existence for best proximiti points, Nonlinear Anal., 5(2009), no. 4, 3665-3671.

[3] S. Banach, Sur les opérations dans les ensembles abstraits et leur application aux équations intégrales, Fund. Math., 3(1922), 133-181. 
[4] S. Basha, Best proximity point theorems generalizing the contraction principle, Nonlinear Anal., 74(2011), 5844-5850.

[5] V. Berinde, On the convergence of Ishikawa iteration for a class of quasi contractive operators, Acta Math. Univ. Comen., 73(2004), no. 1, 119-126.

[6] V. Berinde, A convergence theorem for Mann iteration in the class of Zamfirescu operators, An. Univ. Vest Timişoara Ser. Mat.-Inform., 45(2007), no. 1, 33-41.

[7] V. Berinde, Iterative Approximation of Fixed Points, 2nd Ed., Springer Verlag, Berlin Heidelberg New York, 2007.

[8] V. Berinde, M, Berinde, On Zamfirescu's fixed point theorem, Rev. Roumaine Math. Pures Appl., 50(2005), 443-453.

[9] S.K. Chatterjea, Fixed-point theorems, C.R. Acad. Bulgare Sci., 25(1972), 727-730.

[10] M. Cvetković, V. Rakočević, Quasi-contraction of Perov type, Appl. Math. Comput., 235 (2014), 712-722.

[11] A.A. Eldered, P. Veeramani, Existence and convergence of best proximity points, J. Math. Anal. Appl., 323(2006), 1001-1006.

[12] Lj. Gajić, V. Rakočević, Quasi-contractions on a nonnormal cone metric space, Funct. Anal. Appl., 46(2012), no. 1, 75-79.

[13] R.H. Haghi, V. Rakočević, S. Rezapour, N. Shahzad, Best proximity results in regular cone metric spaces, Rend. Circ. Mat. Palermo, 60(2011), 323-327.

[14] L.G. Huang, X. Zhang, Cone metric spaces and fixed point theorems of contractive mappings, J. Math. Anal. Appl., 332(2007), 1468-1476.

[15] S. Janković, Z. Kadelburg, S. Radenović, On the cone metric space: a survey, Nonlinear Anal., 74(2011), 2591-2601.

[16] G. Jungck, S. Radenović, S. Radojević, V. Rakočević, Common fixed point theorems for weakly compatible pairs on cone metric spaces, Fixed Point Theory Appl., (2009), Article ID 643840, 13 pages.

[17] R. Kannan, Some results on fixed points-II, Amer. Math. Monthly, 76(1969), 405-408.

[18] W.A. Kirk, P.S. Srinivasan, P. Veeramani, Fixed points for mappings satisfying cyclical contractive conditions, Fixed Point Theory, 4(2003), 79-89.

[19] A.I. Perov, On Cauchy problem for a system of ordinary differential equations (Russian), Priblizhen. Metody Reshen. Difer. Uravn., 2(1964), 115-134.

[20] A.I. Perov, A.V. Kibenko, On a certain general method for investigation of boundary value problems (Russian), Izv. Akad. Nauk SSSR Ser. Mat., 30(1966), 249-264.

[21] G. Petruşel, Cyclic representations and periodic points, Stud. Univ. Babeş-Bolyai Math., 50(2005), 107-112.

[22] S. Radenović, B.E. Rhoades, Fixed point theorem for two non-self mappings in cone metric spaces, Comput. Math. Appl., 57(2009), 1701-1707.

[23] Sh. Rezapour, R. Hamlbarani, Some notes on the paper "Cone metric spaces and fixed point theorems of contractive mappings", J. Math. Anal. Appl., 345(2008), 719-724.

[24] B.E. Rhoades, A comparison of various definitions of contractive mappings, Trans. Amer. Math. Soc., 226(1977), 257-290.

[25] I.A. Rus, Generalized Contractions and Applications, Cluj University Press, Cluj-Napoca, 2001.

[26] I.A. Rus, Fixed point theory in partial metric spaces, Analele Univ. de Vest, Timişoara Seria Matematica-Informatica, 46(2008), 149-160.

[27] N. Sultana, A. Hussain, Best proximity point result of quasi contraction in cone metric spaces, Science International (Lahore), 28(2016), no. 2, 781-786.

[28] T. Zamfirescu, Fix point theorems in metric spaces, Arch. Math. (Basel), 23(1972), 292-298.

Received: June, 27, 2017; Accepted: October 10, 2018. 
